Vol 2 No 2 Desember 2021

Jurnal AlphaEuclidEdu

Received: 21/09/2021; Resived: 30/10/2021; Accepted: 31/12/2021

\title{
POTENSI PESERTA DIDIK TIPE QUITTER MENYELESAIKAN SOAL OPEN-ENDED MATERI SEGIEMPAT DAN SEGITIGA
}

\author{
${ }^{1}$ Natalia, ${ }^{2}$ Sugiatno, ${ }^{3}$ Silvia Sayu \\ ${ }^{1,2,3}$ Program Studi Pendidikan Matematika FKIP UNTAN \\ Email: natalia00055@gmail.com
}

\begin{abstract}
This study aims to determine the potential description of quitter type students in solving an open-ended question in the material of Quadrilateral and Triangle at SMP Negeri 20 Pontianak. The research method used is a descriptive method with a qualitative approach and a case study research form. The number of subjects in this study was 27 students of class VIII F SMP Negeri 20 Pontianak. The data collection tool used was the Adversity Response Profile $(A R P)$ to get quitter type subjects, open-ended test questions, and interview guides with the help of teaching aids to probe deeper into the potential of quitter-type students. The results of the research on the written test showed that the potential of 2 quitter subjects in solving open-ended questions was still low with a percentage of only $22.22 \%$. However, when interviewed with the help of teaching aids, additional information was obtained that the two quitter subjects showed better potential in solving open-ended questions and were able to provide more than one solution and more than one correct answer.
\end{abstract}

Keywords: Open-Ended question-Solving Potential, Adversity Quotient Quitter Type, Quadrilateral, and Triangle.

\section{Pendahuluan}

Permasalahan mengenai penggembangan potensi peserta didik menjadi perhatian utama dalam program pendidikan. Sekolah sebagai lembaga pendidikan formal bertanggung jawab membantu mempersiapkan peserta didik agar dapat meningkatkan pengetahuan, keterampilan, dan keahlian sesuai dengan potensinya masing-masing. Tuntutan mengenai penggembangan potensi peserta didik dan cara meningkatkannya menjadi tantangan besar bagi guru untuk mewujudkannya.

Terkait dengan tujuan pendidikan untuk mengembangkan potensi peserta didik, Permendikbud No. 22 tahun 2016 yang mengatur tentang Standar Pendidikan Nasional terkait Standar Proses menyatakan bahwa hendaknya proses pendidikan dilaksanakan secara interaktif, inspiratif, menyenangkan, menantang, memotivasi peserta didik untuk berpartisipasi aktif, serta membuat ruang yang cukup bagi perkembangan kreativitas, serta kemandirian sesuai dengan bakat, minat, dan perkembangan fisik serta psikologis peserta didik. Demi tercapainya regulasi tersebut, guru harus menentukan strategi pembelajaran yang dapat memberikan kebebasan berpikir peserta didik secara aktif dan kreatif. Karena segala sesuatu yang peserta didik pelajari hampir seluruhnya bergantung pada pengalaman guru dalam mengajar di dalam kelas setiap harinya, untuk itu hendaknya peserta didik diberikan soal-soal yang dapat menggembangkan potensi mereka secara aktif.

Salah satu solusi yang ditawarkan yaitu dengan memberikan soal-soal Openended yang mempunyai beragam metode dan jawaban penyelesaian sehingga membuat peserta didik secara interaktif menuangkan ide-ide sesuai dengan kesulitan dan kemampuan yang dimiliki (Lestari \& Yudhanegara, 2015). Tujuan diberikannya soal 
Vol 2 No 2 Desember 2021

Jurnal AlphaEuclidEdu

Received: 21/09/2021; Resived: 30/10/2021; Accepted: 31/12/2021

open-ended bukan di lihat dari hasil akhirnya melainkan proses untuk mencapai hasil tersebut, peserta didik dapat mengembangkan metode atau cara penyelesaian yang berbeda saat menyelesaikan soal sehingga dengan beragamnya jawaban yang diberikan dapat terlihat potensi-potensi yang selama ini masih terpendam dalam diri peserta didik.

Namun pada kenyataannya saat menyajikan soal dalam pembelajaran matematika, guru jarang memberikan soal-soal open-ended kepada peserta didik. Hal ini dapat diketahui dari hasil wawancara dengan seorang guru matematika di SMPN 20 Pontianak pada tanggal 8 Agustus 2020 yaitu Ibu Kusnengsih,S.Pd yang menggatakan bahwa beliau belum pernah memberikan soal-soal open-ended melainkan memberikan soal pilihan ganda yang hanya menuntut satu jawaban saja. Soal yang diberikan di sekolah cenderung hanya menekankan pada penghapalan rumus dengan tidak memberikan kebebasan berpikir secara mandiri dan kreatif kepada peserta didik. Akibatnya peserta didik menjadi kurang tertantang dengan soal yang diberikan sehingga mereka tidak aktif menggali potensi yang dimilikinya. Oleh karena itu, potensi peserta didik dalam menyelesaikan soal open-ended perlu dilatih dan dikembangkan agar peserta didik dapat menafsirkan suatu permasalahan dari berbagai sudut pandang yang berbeda dan menghasilkan ide-ide baru dalam menyelesaikan suatu masalah yang jarang diberikan oleh kebanyakan orang.

Satu di antara materi matematika yang dapat diadaptasi menjadi soal open-ended adalah materi bangun datar segiempat dan segitiga. Materi ini termasuk dalam ruang lingkup aspek geometri yang dipelajari di kelas VII SMP. Salah satu kompetensi dasar yang harus dicapai oleh peserta didik pada materi tersebut yaitu peserta didik dapat menyelesaikan soal kontekstual yang berkaitan dengan luas dan keliling segiempat dan segitiga. Demi tercapainya kompetensi yang diharapkan, peserta didik tidak cukup hanya diberikan soal tertutup saja tetetapi diperlukan juga pemberian soal open-ended yang dapat menggembangkan potensi peserta didik secara lebih aktif melalui permasalahan-permasalahan matematika yang menekankan pada pola pikir kreatif guna menyelesaikan soal dengan banyak cara dan banyak jawaban yang benar.

Dalam proses pembelajaran guru harus menyadari bahwa semakin banyak peserta didik maka semakin tinggi pula kemajemukan yang ada di kelas. Hal ini sejalan dengan pendapat Darling-Hammond dkk (Gollub, 2002:59) yang menyatakan dalam pendidikan, guru harus siap menghadapi keragaman substansial dalam pengalaman peserta didik di sekolah seperti bahasa, budaya, kekhasan, gaya belajar, bakat dan kecerdasan. Berdasarkan pengalaman PPL disekolah, peneliti menyadari sekali adanya keragaman yang terjadi di kelas terutama perbedaan kecerdasan peserta didik saat menghadapi kesulitan dalam pembelajaran matematika yang diperkenalkan oleh Stoltz sebagai Adversity Quotient (AQ). Menurut Stoltz Adversity Quotient merupakan salah satu kecerdasan selain IQ dan EQ yang dapat menilai seberapa baik seseorang dapat bertahan atau tidak saat menghadapi kesulitan dan tantangan (Stoltz, 2000). Demikian pula dalam pembelajaran matematika yang penuh dengan tantangan, guru harus mempertimbangkan AQ peserta didik agar pembelajaran matematika dapat menjadi sukses. Kesulitan yang muncul menjadi tantangan tersendiri bagi peserta didik yang tidak mampu menghadapi kesulitan, sehingga dapat memengaruhi tingkat keberhasilannya dalam pembelajaran matematika.

Stoltz (2000: 18) membagi tiga tipe individu di lihat dari tanggapannya menghadapi kesulitan yaitu, quitter (individu dengan AQ rendah), camper (individu 
Vol 2 No 2 Desember 2021

Jurnal AlphaEuclidEdu

Received: 21/09/2021; Resived: 30/10/2021; Accepted: 31/12/2021

dengan AQ sedang), dan climber (individu dengan AQ tinggi). Quitter ditujukan untuk individu yang mudah putus asa dan kurang memiliki dorongan kuat dalam menerima tantangan dalam hidupnya. Camper ditujukan kepada individu yang mudah puas dengan apa yang dicapai dan tidak mau mengorbankan apa yang telah diperolehnya sehingga memilih mundur ketika merasa tidak berdaya lagi. selanjutnya, Climber ditujukan kepada orang yang selalu bersikeras untuk selalu berjuang ketika dihadapkan dengan bermacam kesulitan yang menghambatnya (Wulandari et al., 2020); (Jamiah, 2020).

Melihat fenomena yang sering terjadi di kelas, guru cenderung lebih fokus pada peserta didik tipe climber dan camper serta mengabaikan peserta didik tipe quitter sehingga membuat mereka kurang terakomodir dalam pembelajaran. Hal yang perlu diperhatikan adalah memberikan kesempatan bagi peserta didik tipe quitter untuk membuka kembali peluang keberhasilan dalam pembelajarannya. Peserta didik quitter sangat membutuhkan bantuan guru karena mereka cenderung mudah menyerah, cepat putus asa, pasif, dan tidak bersemangat mencapai puncak penyelesaian suatu masalah. Berdasarkan pada prinsip pembelajaran (NCTM 2000:12) yaitu dalam pembelajaran matematika semua peserta didik terlepas dari karakteristik pribadi, latar belakang, atau tantangan, harus memiliki kesempatan dan dukungan untuk belajar yang setara. Oleh karena itu, sebagai guru wajib memahami perbedaan AQ yang ada didalam peserta didik guna merancang strategi pembelajaran yang sesuai, sehingga potensi yang ada dalam diri peserta didik tipe quitter yang cenderung mudah menyerah, putus asa, pasif, dan tidak bersemangat mencapai puncak dapat dikembangkan dengan maksimal.

Berdasarkan permasalahan di atas, penting bagi guru untuk memberikan soalsoal yang dapat mengembangkan potensi peserta didik dengan tetap memperhatikan adversity quotient karena setiap peserta didik mempunyai potensi dan kemampuan mengatasi kesulitan yang berbeda-beda. Oleh karena itu, dirasa perlu untuk diteliti lebih lanjut terkait potensi menyelesaikan soal open-ended yang ada pada peserta didik tipe quitter. Melalui penelitian ini peneliti tertarik untuk mengambil judul "Potensi Peserta Didik Menyelesaikan Soal Open-Ended Dikaji Dari Adversity Quotient Tipe Quitter Dalam Materi Segiempat dan Segitiga di SMP Negeri 20 Pontianak".

Bersumber pada latar belakang masalah yang telah diuraikan, maka rumusan masalah dari penelitian ini adalah "Bagaimana potensi peserta didik tipe Quitter menyelesaikan soal Open-Ended dalam materi Segiempat dan Segitiga di SMP Negeri 20 Pontianak ?'. Secara umum, tujuan dari riset ini adalah untuk mengetahui gambaran potensi peserta didik tipe quitter menyelesaikan soal open-ended dalam materi segiempat dan segitiga di SMP Negeri 20 Pontianak.

\section{Metode Penelitian}

Berdasarkan tujuan penelitian yang dipaparkan, riset ini menggunakan metode deskriptif dengan pendekatan kualitatif. Bentuk penelitian yang digunakan adalah bentuk penelitian studi kasus. Menurut Susilo Rahardjo dan Gudnanto (2011) studi kasus diartikan sebagai cara yang diterapkan untuk memahami objek secara lebih mendalam dengan dipraktekkan secara integratif serta komprehensif. Menurut Gall dkk. (2003), penelitian korelasional bertujuan untuk menentukan relasi antar variabel dengan pemakaian formula statistik korelasional.

Subjek dalam penelitian ini adalah adalah peserta didik kelas VIII F SMP Negeri 20 Pontianak yang memiliki AQ tipe quitter dan telah mempelajari materi segiempat 
Vol 2 No 2 Desember 2021

Jurnal AlphaEuclidEdu

Received: 21/09/2021; Resived: 30/10/2021; Accepted: 31/12/2021

dan segitiga. Sedangkan objek dalam penelitian ini adalah potensi peserta didik tipe quitter menyelesaikan soal open-ended, khususnya dalam materi segiempat dan segitiga. Teknik pengumpulan data yang digunakan adalah teknik tes dan komunikasi langsung. Teknik tes yang dimaksud dalam penelitian ini berupa tes soal open-ended untuk melihat potensi open-ended peserta didik pada materi segiempat dan segitiga. Tes juga dilakukan untuk menggelompokkan tipe adversity quotient yaitu: climber, camper, dan quitter melalui pemberian ARP (Adversity Response Profile) yang memuat empat dimensi AQ yaitu kendali diri (control), asal- usul dan pengakuan (origin dan ownership), jangkauan (reach), dan daya tahan (endurance). Teknik komunikasi tak langsung berupa wawancara semi terstruktur dengan bantuan alat peraga berupa tangram. Penggunaan alat peraga dalam wawancara ini guna membantu peneliti dalam menggali potensi peserta didik menyelesaikan soal open ended yang tidak dapat terlihat melalui tes tertulis.

Instrumen penelitian yang digunakan untuk melihat potensi peserta didik menyelesaikan soal open-ended diantaranya kisi-kisi soal tes open-ended, soal tes openended, alternatif penyelesaian, dan rubrik penskoran yang telah divalidasi oleh satu orang dosen Pendidikan Matematika FKIP Universitas Tanjungpura dan satu orang guru matematika SMPN 20 Pontianak. Instrumen yang digunakan untuk mengukur adversity quotient berupa kisi-kisi ARP (Adversity Response Profile), dan ARP (Adversity Response Profile) yang telah divalidasi oleh satu orang dosen Bimbingan dan Konseling FKIP Universitas Tanjungpura dan satu orang guru matematika SMPN 20 Pontianak. Karena dalam kondisi pandemi COVID-19 pengumpulan data penelitian dilakukan secara online melalui aplikasi Whatsapp. Setelah terkumpul, data tersebut dianalisis.

Prosedur yang dilakukan dalam penelitian ini terdiri dari tiga tahap sebagai berikut:

\section{Tahap Persiapan}

Langkah-langkah yang dilakukan pada tahap persiapan antara lain: (a) Melakukan observasi awal melalui wawancara dengan guru matematika SMPN 20 Pontianak; (b) Menyusun instrumen penelitian berupa ARP (Adversity Responsse Profile), tes soal open-ended, serta pedoman wawancara; (c) Melakukan validasi instrumen penelitian serta melakukan revisi instrumen penelitian berdasarkan hasil validasi; (d) Melakukan uji coba terhadap instrumen penelitian; (e) Menganalisis dan merevisi data hasil uji coba instrumen.

\section{Tahap Pelaksanaan}

Yang dilakukan pada tahap pelaksanaan yaitu: (a) Memberikan instrumen penelitian berupa tes soal open-ended dan angket ARP (Adversity Response Profile) kepada peserta didik; (b) Menganalisis hasil ARP dan menggolongkan peserta didik sesuai dengan tipe AQ, dalam penelitian ini akan diambil peserta didik dengan tipe quitter; (c) Menganalisis jawaban hasil tes soal open-ended peserta didik tipe quitter; (d) Melakukan wawancara terhadap peserta didik tipe quitter terkait jawaban hasil tes peserta didik.

\section{Tahap Pelaporan}

Langkah-langkah yang dilakukan pada tahap ini yaitu: (a) Membuat kesimpulan dengan cara merangkum data hasil pendeskripsian penelitian; (b) Menyusun laporan setelah semua data yang diperlukan lengkap. 
Vol 2 No 2 Desember 2021

Jurnal AlphaEuclidEdu

Received: 21/09/2021; Resived: 30/10/2021; Accepted: 31/12/2021

\section{Hasil dan Pembahasan}

\section{Hasil Penelitian}

\section{Adversity Quotient Peserta Didik}

Adversity Responsse Profile (ARP) diberikan kepada 27 peserta didik dan berisi 13 pernyataan yang masing-masing pernyataan diikuti oleh dua pertanyaan (26 item) yang memuat 4 indikator untuk mengukur tingkat AQ. Data hasil ARP diolah menggunakan program Ms. Excel 2010. Penskoran ARP bersifat normatif, yang artinya semakin tinggi skor AQ seseorang kemungkinan semakin tinggi pula kemampuannya dalam merespon kesulitan. Berikut jumlah skor dan kategori tingkat AQ subjek penelitian.

Tabel 1. Skor ARP dan Kategori Adversity Quotient Peserta Didik

\begin{tabular}{|c|c|c|c|}
\hline Kategori Adversity Quotient & $\begin{array}{l}\text { Kode Peserta } \\
\text { Didik }\end{array}$ & Jumlah & Persentase \\
\hline Climber & $\begin{array}{c}\text { S1, S2, S4, S5, } \\
\text { S7, S11, S13, S16, } \\
\text { S18, S20, S22, S24, } \\
\text { S25, S26 }\end{array}$ & 14 orang & $51,8 \%$ \\
\hline Camper & $\begin{array}{c}\text { S3, S6, S8, S9, } \\
\text { S10, S12, S15, S17, } \\
\text { S19,S23, S27 }\end{array}$ & 11 orang & $40,7 \%$ \\
\hline Quitter & $\mathrm{S} 14, \mathrm{~S} 21$ & 2 orang & $7,4 \%$ \\
\hline
\end{tabular}

Tabel 1 menunjukkan 14 orang peserta didik memiliki AQ yang tinggi (tipe climber), 11 orang memiliki AQ sedang (tipe camper) dan 2 orang memiliki AQ rendah (tipe quitter). Dalam penelitian ini hanya difokuskan kepada peserta didik dengan tingkat AQ rendah (tipe quitter) maka hanya 2 orang subjek yang akan dianalisis lebih lanjut hasil jawaban tes soal open-ended.

\section{Potensi Peserta Didik Tipe Quitter Menyelesaikan Soal Open-Ended}

Untuk mengetahui potensi peserta didik dalam menyelesaikan soal open-ended diukur menggunakan tes soal open-ended. Tes yang diberikan berupa dua soal uraian materi segiempat dan segitiga yang telah divalidasi dan diuji cobakan. Data hasil tes keterampilan problem solving matematis, diolah menggunakan Ms. Excel 2010. Skor hasil tes soal open-ended peserta didik tipe quitter disajikan di dalam tabel berikut.

Tabel 2. Hasil Tes Potensi dalam Menyelesaikan Soal Open-Ended Peserta Didik Tipe Quitter

\begin{tabular}{|c|c|c|c|c|c|c|c|}
\hline \multirow{2}{*}{ No } & \multirow{2}{*}{ Subjek } & \multicolumn{3}{|c|}{ Skor } & \multirow{2}{*}{ Jumlah } & \multirow{2}{*}{$\%$} & \multirow{2}{*}{ Kategori } \\
\hline & & 1 & $2 a$ & $2 b$ & & & \\
\hline 1 & S14 & 1 & 2 & 0 & 3 & $16,66 \%$ & Kurang \\
\hline 2 & S21 & 2 & 2 & 1 & 5 & $27,77 \%$ & Cukup \\
\hline \multicolumn{2}{|c|}{ Jumlah } & 3 & 4 & 1 & 8 & $44,44 \%$ & \\
\hline \multicolumn{2}{|c|}{ Rata-rata } & \multicolumn{2}{|c|}{3,5} & 0,5 & 4 & $22,22 \%$ & \\
\hline
\end{tabular}


Vol 2 No 2 Desember 2021

Jurnal AlphaEuclidEdu

Received: 21/09/2021; Resived: 30/10/2021; Accepted: 31/12/2021

Tabel 2 menunjukkan bahwa rata-rata persentase skor secara keseluruhan yaitu sebesar 22,22\% dan termasuk dalam kategori kurang. Skor per indikator yang diperoleh yaitu pada aspek terbuka jawabannya dengan rata-rata persentase skor sebesar 3,5\% dan aspek terbuka hasil akhirnya dengan rata-rata skor sebesar $0,5 \%$. Hal ini menunjukkan bahwa potensi peserta didik tipe quitter dalam menyelesaikan soal open-ended masih relatif rendah, ini dapat terlihat dari hasil pekerjaan peserta didik yang hanya menyelesaikan soal dengan 1 jawaban serta 1 cara penyelesaian yang rutin dilakukan.

\section{Hasil Wawancara}

Berdasarkan Tabel 4.1 dan Tabel 4.2 selanjutnya kedua subjek penelitian akan diambil untuk dilakukan wawancara mendalam. Karena pada hasil tes soal open-ended secara tertulis peserta didik tipe quitter belum mampu menunjukkan potensinya dalam menyelesaikan soal, maka pada saat wawancara peneliti menggunakan bantuan alat peraga berupa tangram untuk membantu menggali potensi peserta didik dalam menjawab soal open-ended. Adapun perubahan kemampuan peserta didik tipe quitter dalam menyelesaikan soal open-ended setelah wawancara disajikan di dalam tabel berikut.

Tabel 3. Perubahan Potensi Peserta Didik Tipe Quitter

\begin{tabular}{|c|c|c|}
\hline $\begin{array}{c}\text { Subjek } \\
\text { Penelitian }\end{array}$ & $\begin{array}{c}\text { Jawaban Subjek Sebelum } \\
\text { Wawancara }\end{array}$ & $\begin{array}{c}\text { Jawaban Subjek Saat } \\
\text { Wawancara }\end{array}$ \\
\hline \multirow{3}{*}{ S14 } & $\begin{array}{l}\text { Hanya memberikan satu } \\
\text { jawaban dengan ukuran keramik } \\
1 \mathrm{~cm} \times 1 \mathrm{~cm} \text {, dan tidak bisa } \\
\text { mencari luas dari permukaan } \\
\text { lantai }\end{array}$ & $\begin{array}{l}\text { Mampu memberikan dua } \\
\text { jawaban yang berbeda yaitu } \\
\text { menjawab dengan ukuran } \\
\text { keramik } 1 \mathrm{~cm} \text { x } 1 \mathrm{~cm} \text { dan } 1 \mathrm{~cm} \mathrm{x} \\
2 \mathrm{~cm} \text {, dan mencari luas } \\
\text { permukaan lantai dengan benar }\end{array}$ \\
\hline & $\begin{array}{l}\text { Hanya membuat satu gambar } \\
\text { persegi dari potongan } 3 \text { dan } 5\end{array}$ & $\begin{array}{l}\text { Mampu membuat dua gambar } \\
\text { persegi yang berbeda yaitu } \\
\text { persegi } 1 \text { (potongan } 3 \text { dan 5) dan } \\
\text { persegi } 2 \text { (potongan } 3,5 \text { dan } 7 \text { ) }\end{array}$ \\
\hline & Tidak memberikan jawaban & $\begin{array}{l}\text { Mampu mencari luas persegi } \\
\text { dengan dua cara penyelesaian }\end{array}$ \\
\hline \multirow{3}{*}{ S21 } & $\begin{array}{l}\text { Hanya memberikan satu } \\
\text { jawaban dengan ukuran keramik } \\
1 \mathrm{~cm} \text { x } 2 \mathrm{~cm} \text {, dan menjawab luas } \\
\text { dari permukaan lantai dengan } \\
\text { benar }\end{array}$ & $\begin{array}{l}\text { Mampu memberikan tiga } \\
\text { jawaban yang bervariasi yaitu } \\
\text { menjawab dengan ukuran } \\
\text { keramik } 1 \mathrm{~cm} \times 2 \mathrm{~cm}, 1 \mathrm{~cm} \times 1 \mathrm{~cm} \text {, } \\
\text { dan } 1 \mathrm{~cm} \times 4 \mathrm{~cm}\end{array}$ \\
\hline & $\begin{array}{l}\text { Hanya membuat satu gambar } \\
\text { persegi dari potongan } 3,5 \text { dan } 7\end{array}$ & $\begin{array}{l}\text { Mampu membuat tiga gambar } \\
\text { persegi yang berbeda yaitu } \\
\text { persegi } 1 \text { (potongan } 3,5 \text { dan } 7 \text { ) } \\
\text { persegi } 2 \text { (potongan } 3 \text { dan } 5 \text { ) } \\
\text { persegi } 3 \text { (potongan } 1 \text { dan 2) }\end{array}$ \\
\hline & $\begin{array}{l}\text { Memberikan satu cara } \\
\text { penyelesaian tetapi keliru }\end{array}$ & $\begin{array}{l}\text { Mampu mencari luas persegi } \\
\text { dengan dua cara penyelesaian }\end{array}$ \\
\hline
\end{tabular}


Vol 2 No 2 Desember 2021

Jurnal AlphaEuclidEdu

Received: 21/09/2021; Resived: 30/10/2021; Accepted: 31/12/2021

Berdasarkan Tabel 3, dari hasil wawancara yang sudah dilakukan ditemukan bahwa kedua peserta didik tipe quitter ini menunjukkan potensi menyelesaikan soal open-ended yang baik setelah dibantu dengan alat peraga. Dalam menyelesaikan soal open-ended, kedua peserta didik quitter ini mengerti dengan maksud soal tersebut namun ketika saat mengerjakannya mereka menemukan kesulitan atau berbeda dari soal rutin yang biasa mereka temui mereka memilih berhenti dan tidak mengerjakan soal tersebut.

\section{Pembahasan}

Berdasarkan Tabel 1, adversity quotient peserta didik dikelompokkan dalam 3 tingkatan, yaitu climber, camper, dan quitter. Karena dalam penelitian ini hanya diambil peserta didik tipe quitter, secara umum dari 27 orang peserta didik terdapat 2 orang yang termasuk dalam tipe quitter dengan persentase sebesar 7,4\% dan masing-masing skor ARP nya 42 dan 53. Dari hasil analisis skor ARP, subjek S14 memperoleh skor ARP sebesar 42 dengan masing-masing skor dimensi Control 16, Origin-Ownership 10, Reach 8, dan Endurance 8. Sedangkan subjek S21 memperoleh skor ARP sebesar 53 dengan masing-masing skor dimensi Control 17, Origin-Ownership 11, Reach 12, dan Endurance 6. Grafik perbandingan skor CO2RE masing-masing subjek sebagai berikut.

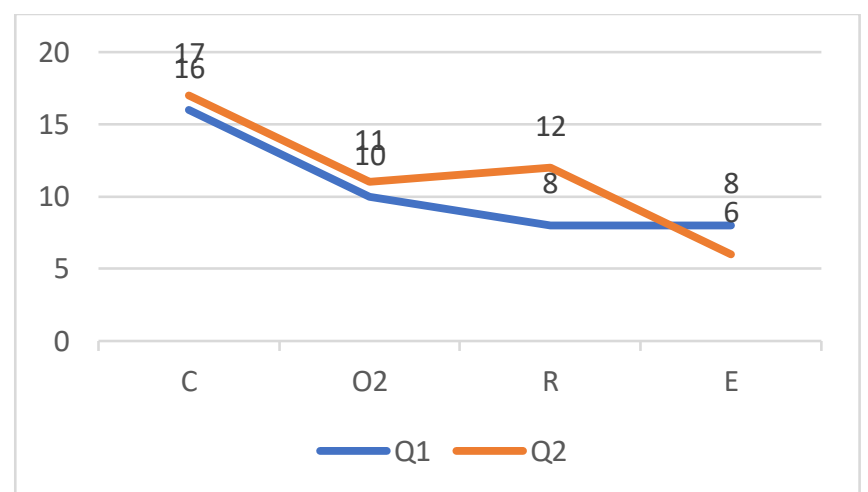

Gambar 1. Grafik Perbandingan Skor CO2RE Subjek S14 dan S21

Berdasarkan analisis data hasil tes, diperoleh bahwa potensi peserta didik tipe quitter dalam menyelesaikan soal open-ended masih rendah. Hal tersebut dapat di lihat dari Tabel 2 yang menunjukkan rata-rata persentase hasil tes potensi kedua peserta didik tipe quitter dalam menyelesaikan soal open-ended secara keseluruhan hanya sebesar $22,22 \%$. Jika di lihat lebih spesifik, skor per indikator potensi peserta didik saat menyelesaikan soal open-ended pada aspek terbuka jawabannya dan aspek terbuka prosesnya termasuk dalam kategori rendah.

Pada soal nomor 1 dan 2a dengan indikator soal yang terbuka jawabannya (mempunyai banyak jawaban yang benar), subjek S14 memperoleh skor 1 dan 2 sementara subjek S21 memperoleh skor 2 dan 2. Berdasarkan rubrik penskoran tes soal open-ended peserta didik memperoleh skor 1 jika memberikan 1 jawaban namun kurang jelas dan belum selesai, dan memperoleh skor 2 jika dapat memberikan 1 jawaban dengan benar, jelas dan lengkap. Hal ini mengindikasikan bahwa subjek S14 dan S21 hanya mampu menyelesaikan soal open-ended dengan 1 jawaban saja. Hal serupa juga ditemukan oleh Sudarman (2011) dalam penelitiannya, ia mengungkapkan bahwa 
Vol 2 No 2 Desember 2021

Jurnal AlphaEuclidEdu

Received: 21/09/2021; Resived: 30/10/2021; Accepted: 31/12/2021

peserta didik tipe quitter saat menggerjakan tugas menunjukkan sikap yang tidak bersemangat, usaha yang minim, dan bekerja seadanya.

Pada soal nomor $2 \mathrm{~b}$ dengan indikator soal yang terbuka prosesnya (mempunyai banyak cara penyelesaian yang benar), subjek S14 memperoleh skor 0 dan subjek S21 memperoleh skor 1. Berdasarkan rubrik penskoran peserta didik memperoleh skor 0 jika tidak memberikan jawaban dan skor 1 jika menjawab dengan menggunakan 1 cara penyelesaian, tetetapi tidak selesai dan keliru. Dari skor ini tampak bahwa subjek S14 sama sekali tidak menuliskan cara mencari luas persegi yang dibuatnya, ini dikarenakan subjek tidak memahami dengan baik maksud dari soal tersebut dan saat mengerjakan soal ini dia mendapati kesulitan ia memilih untuk berhenti dan tidak mengerjakannya sama sekali. Hal ini sesuai dengan teori Stoltz (2000:18) yang menyatakan bahwa individu dengan tipe quitter cenderung memilih untuk menghindari kewajiban, mundur dan berhenti saat menjumpai kesulitan.

Menyadari setiap manusia lahir membawa potensinya masing-masing, sama halnya dengan peserta didik tipe quitter juga mempunyai potensi yang dapat digali dan dikembangkan melalui proses pembelajaran. Jika di lihat dari jawaban hasil tes, peserta didik tipe quitter belum menunjukkan potensinya dalam menyelesaikan soal openended. Sesuai dengan pernyataan Stoltz (2000:34) yang meyakini bahwa quitter tidak selalu ditakdirkan untuk kehilangan kesempatan namun dengan berbagai bantuan dan dorongan, quitter akan mendapat kekuatan untuk bertahan dalam menghadapi kesulitan yang sedang ia hadapi. Untuk itu, pada saat wawancara peneliti berusaha untuk menggali potensi peserta didik tipe quitter lebih dalam dengan variasi bantuan alat peraga berupa tangram.

Berdasarkan hasil wawancara, ditemukan fakta bahwa subjek S14 dan S21 menunjukkan potensi menyelesaikan soal open-ended yang lebih baik ketika diwawancara dengan bantuan alat peraga dibandingkan dengan hasil tes tertulis.

\section{Kesimpulan dan Saran Kesimpulan}

Berdasarkan analsisis hasil tes, diperoleh kesimpulan bahwa potensi peserta didik tipe quitter menyelesaikan soal open-ended dalam materi segiempat dan segitiga pada tes tertulis masih rendah dengan persentase hanya sebesar $22,22 \%$. Hal ini tampak pada hasil tes tertulis yang menunjukkan bahwa peserta didik tipe quitter hanya mampu menyelesaikan soal dengan satu cara penyelesaian dan satu jawaban saja. Namun ketika diwawancara lebih dalam dan dibantu dengan alat peraga diperoleh informasi tambahan bahwa peserta didik quitter menunjukkan potensi yang lebih baik yakni mampu menjawab lebih dari satu cara penyelesaian dan lebih dari satu jawaban dengan benar.

\section{Saran}

Adapun saran-saran yang dapat peneliti berikan adalah sebagai berikut: (1) Bagi peserta didik, diharapkan dapat meningkatkan kemampuan adversity quotient agar tidak mudah menyerah saat menjumpai kesulitan dalam pembelajaran matematika sehingga potensi-potensi yang dimiliki dapat dimanfaatkan dengan baik. (2) Bagi guru, hendaknya dalam mengajar lebih memperhatikan perbedaan adversity quotient yang ada pada peserta didik agar dapat merancang pembelajaran sesuai dengan kebutuhan dan kesulitan peserta didik sehingga potensi perseta didik dapat tergali dengan maksimal. (3) Bagi peneliti selanjutnya, diharapkan dapat melakukan penelitian dengan 
Vol 2 No 2 Desember 2021

Jurnal AlphaEuclidEdu

Received: 21/09/2021; Resived: 30/10/2021; Accepted: 31/12/2021

menggunakan strategi dan tindakan khusus lainnya sehingga dapat menggali potensi peserta didik tipe quitter lebih maksimal.

\section{Referensi}

Gollub, J. P. (2002). Learning and Understanding: Improving Advanced Study of Mathematics and Science in U.S High Schools. Washington, DC: National Academy Press.

Jamiah, Y. (2020). Penguatan Karakter Siswa Perbatasan Melalui Internalisasi Kearifan Lokal Dalam Pembelajaran Matematika. Jurnal AlphaEuclidEdu, 1(2), 69. https://doi.org/10.26418/ja.v1i2.43306

Wulandari, A. C., Sugiatno, S., \& Bistari, B. (2020). Tantangan Belajar Matematika Dalam Materi Aritmatika Sosial Pada Peserta Didik Berkebutuhan Khusus. Jurnal AlphaEuclidEdu, 1(2), 135. https://doi.org/10.26418/ja.v1i2.42898

Lestari dan Yudhanegara. 2015. Penelitian Pendidikan Matematika. Bandung : PT. Refika Aditama.

National Council of Teachers of Mathematics. (2000). Principles and standards for school mathematics. Reston, VA: NCTM.National Council of Teachers of Mathematics (2005). The Open-Ended Approach: A New Proposal for Teaching Mahematics. Reston, VA: NCTM.

Prihadhi, Endra K. (2004). My Potensi. Jakarta: Elek Media Komputindo.

Stoltz, Paul G. (2000). Adversity Quotient: Mengubah hambatan menjadi peluang. Alih bahasa T. Hermaya. Jakarta: PT Gramedia Widiasarana Indonesia (Grasindo).

Sudarman. (2011). Proses Berpikir Siswa Quitter Pada Sekolah Menengah Pertama Dalam Menyelesaikan Masalah Matematika. Jurnal Edumatica 1(2)

Susilo Rahardjo \& Gudnanto. (2011). Pemahaman Individu Teknik Non Tes. Kudus: Nora Media Enterprise.

Gall, Meredith D., Joyce P. Gall, and Borg, W. (2003). Educational research : an Introduction. Boston : pearson education Inc. 